\title{
ENTREPRENEURIAL ORIENTATION AND EXTERNAL TECHNOLOGY ACQUISITION: AN EMPIRICAL TEST ON PERFORMANCE OF TECHNOLOGY-BASED NEW VENTURES
}

\author{
Li Cai ${ }^{1}$, Qing Liu², Shengliang Deng1, 3, Dan $\mathrm{Cao}^{4}$ \\ ${ }^{1}$ School of Management, Jilin University, Changchun, 130022, China \\ ${ }^{2}$ Centre of Enterprise Research, Jilin University, Changchun, 130022, China \\ ${ }^{3}$ Goodman School of Business, Brock University, St. Catharines, L2S 3A1, Canada \\ ${ }^{4}$ School of International Business Administration, Zhejiang International Studies University, \\ Hangzhou, 310012, China \\ E-mails: ${ }^{1}$ cli@jlu.edu.cn; ${ }^{2}$ qliu@jlu.edu.cn (correspondingauthor); ${ }^{3}$ sdeng@brocku.ca; \\ ${ }^{4}$ dan.cao@hull.edu.uk
}

Received 08 October 2012; accepted 24 January 2013

\begin{abstract}
This research investigates the effects of entrepreneurial orientation and external technology acquisition on the performance of technology-based new ventures in the context of a transitional economy. An analysis of the cross-sectional data from 123 Chinese technology-based new ventures was conducted. The results of the analysis support the contention that both the acquisition of external technology and entrepreneurial orientation improve new ventures' performance. Additionally, the interaction of entrepreneurial orientation and external technology acquisition positively moderates the relationship between entrepreneurial orientation and performance of technology-based new ventures. Overall, this study contributes to our enhanced understanding of the complex relationship among entrepreneurial orientation, external technology acquisition and firm performance under transitional economic conditions. Firms from emerging economies, especially technologybased new ventures, may find the study findings useful in guiding their decision on external technology acquisition.
\end{abstract}

Keywords: technology-based new ventures, entrepreneurial orientation, external technology acquisition, performance, transitional economy, China.

Reference to this paper should be made as follows: Cai, L.; Liu, Q.; Deng, S.; Cao, D. 2014. Entrepreneurial orientation and external technology acquisition: an empirical test on performance of technology-based new ventures, Journal of Business Economics and Management 15(3): 544-561.

JEL Classification: L25, L26, M13, O32.

\section{Introduction}

For the past three decades, the progress of economic and institutional reforms in China has unleashed the economic potential of millions of enterprising individuals. The 2010 Total Entrepreneurial Activity (TEA) index of 14.4\% ranks China the seventh among 
24 efficiency-driven economies and $16^{\text {th }}$ among 59 GEM member countries in terms of active entrepreneurship (GEM 2010). This vigorous pace of new venture creation has contributed to an annual GDP growth rate of more than $9.5 \%$ for nearly three decades and is an important source of new job creation, organizational innovation, and growth of the private sector in China (People's Daily 2011). Past researches have shown that entrepreneurship influences the social and economic development of a country (Lau, Busenitz 2001; Peng 2001; Ahlstrom, Bruton 2002). Therefore, it is a matter of great concern for public policy since entrepreneurship is very critical for the newly emerging private sector to realize its full performance potential.

Recently, Chinese policy-makers have focused their attention on enhancing the global competitiveness of the economy as it relates to technological development and innovation. The $12^{\text {th }}$ Five-Year Program (2011-2016) highlights an "innovation-oriented nation" and "endogenous innovation" strategies as the foundation of sustainable national competitive advantage for China. In technology-intensive industries, new entrepreneurial ventures are key contributors to the implementation of this ambitious national program, because of their flexibility, constant focus on new technology and market opportunities, as well as their willingness to take risks with innovations (People's Daily 2011).

Technology-based firms often exhibit a character of higher level of social value in comparison to other less technology intensive firms (Roberts 1991a). New entrepreneurial venture firms that take a strategic posture tend to have the characteristics of innovation, proactiveness, and willingness to take risks as well as high level of entrepreneurial orientation (EO) (Lumpkin, Dess 1996; Cai et al. 2014). The latter characteristics leads a firm to engage in product market innovation, undertake somewhat risky ventures, and to first come up with proactive innovation, beating competitors to the punch (Pearce et al. 2010). Thus, EO is an effective strategic process in pursuing market opportunities, and enhancing organizational performance (Wiklund 1999; Ortega 2010; Bamiatzi, Kirchmaier 2014).

EO is certainly also critical for firms operating in emerging markets. Yet, most of the research on the link between EO and organizational performance focus on the mature market economy and the nature of this relationship in the context of a transitional economy such as China is still relatively under researched (Bruton et al. 2000; Bruton, Ahlstrom 2003; Chow 2006). As Covin, Slevin (1989) once point out that EO benefits organizational performance even in hostile environments that are full of precarious industry conditions, intense competition, overwhelming harsh business climates and the relative lack of exploitable opportunities. Hence it is worthwhile to investigate this relationship in the Chinese environment, as China's market and institutional environment are more dynamic and volatile compared to mature market economies. Undoubtedly, an in-depth investigation in this area is urgently needed to fill in the research gap in a more comprehensive understanding of the relationship between EO and organizational performance in an ever-changing dynamic environment.

Furthermore, as China moves from an agriculture-based economy to a manufacturebased economy, internal R\&D simply cannot catch up with the fast pace of such transformation. As a result, Chinese firms tend to acquire outside technology resources to 
speed up their modernization process. However, no research has ever been conducted to verify whether such a strategy benefits firm performance. The goal of current study is to uncover the relationship between EO and technology-based new ventures' (TBNV) performance, as well as the impact of external technology acquisition (ETA) on this relationship in the dynamic Chinese transitional economy.

\section{Literature review and hypotheses development}

\subsection{Entrepreneurial orientations and firm performance}

EO refers to a firm's strategic orientation, focusing on specific entrepreneurial aspects of innovativeness, proactivness, and risk-taking. "Innovativeness" reflects a firm's tendency to engage in and support new ideas, novelty, experimentation, and creative process as well as a firm's ability to pursue new opportunities (Lumpkin, Dess 1996). "Proactiveness" refers to ability to act and anticipate market changes with a forward-looking perspective and introduces new products or services as a response to those changes (Voss et al. 2005). "Risk-taking" is the degree of risky behavior in the strategic entrepreneurial process. Overall, entrepreneurial orientation relates to the entrepreneur's methods, practices and decision-making styles (Cools, Van den Broeck 2008; Alegre, Chiva 2013).

The relationship between EO and firm performance is well established in both conceptual and empirical literature on EO. Since 1980s, scholars (Miller 1987; Zahra, Covin 1995; Jones et al. 2000; Wales et al. 2013a) argue for a positive and significant relationship between EO and firm performance. The majority of the empirical studies (Wiklund 1999; Covin et al. 2006; Avlonitis, Salavou 2007; Soininen et al. 2012; Wales et al. 2013b; Real et al. 2014) in this area have validated this relationship. While most of the existing empirical evidence emphasizes that a positive relationship exists between EO and organizational performance, studies conducted in emerging markets show mixed results (Boso et al. 2013). While some studies (Luo et al. 2005; Tsai, Wang 2008) find rather weak relationship between EO and firm performance, especially in state-owned enterprises, others find a positive and significant relationship between EO and firm performance, e.g. the study of 1,100 Chinese enterprises located in Shandong, Inner Mongolia, Hebei and Tianjin by Tang et al. (2008). Nevertheless, in a staged model study of entrepreneurship in China, Tan (2005) reports that after 1990 firms in China show distinctive strategic orientation and that they are far more innovative and riskoriented. Against this background, we hypothesize that:

H1: EO positively improves technology-based new ventures' performance in China.

\subsection{External technology acquisition and firm performance}

Technological resources, such as non-codified knowledge, investment in R\&D and patents, play an important role in growth and development of technology-based firms in transitional economies (Watkins-Mathys, Foster 2006). Although technology-based new ventures tend to become pioneers in introducing new product or technology to the market, a firm's internal R \& D often requires not only hefty resource and capability 
development investments, but also with high uncertain outcomes (Zahra 1996; Friesl 2012). Therefore, external technology acquisition, including purchasing technology/ patents, licensing and technology-based alliances, is often an advantageous strategy for TBNVs as a way to increase their technological knowledge (Cohen, Levinthal 1990; Buckley, Park 2014) and strengthen their technological capabilities (Jones et al. 2000; Lichtenthaler 2010) with minimum uncertainty.

During the economic transitional period, China's technological conditions and environmental change are often more volatile and dynamic (Peng 2003; Tan 2007; Lau et al. 2008;). In such an environment, new firms tend to be compelled to use external sources of technology (Teece 1986; Shan 1990; Zahra, Bogner 1999, Zhou, Li 2013). Recent research suggests that new ventures that use external technology to create new products and services often acquire additional market shares and have higher levels of performance (Zahra, Bogner 1999). A longitudinal study by Tsai and Wang (2008) supports the argument that external technology acquisition is positively correlated with firm performance. Therefore, we propose:

H2: in the context of China, ETA positively influences technology-based new venture's performance.

\subsection{The impact of EO and ETA interaction on firm performance}

Although EO and external technology acquisition both have significant influence on the performance of technology-based new ventures, new firms cannot achieve a maximum level of performance if they only utilize one or the other. While the adoption of EO can help TBNVs to take new initiatives in innovation and pursue more business opportunities, this approach is also a resource-consuming strategy that may weaken a firm's resource base quickly (Covin, Slevin1991). Similarly, while a strategy of ETA can speed up a firm's product development and market expansion, a technology-based new venture may fall into a trap of dependence on the external sources of technology, thus loses its own technological advantage. Therefore, a configuration of EO and ETA may be a more advantageous strategic choice to maximize a firm's performance efficiency.

For TBNVs in China, they face two dilemmas. The first one is the fast pace of economic growth and ever expanding business opportunities coupled with incomplete market and institutional environments (Tan 1996, 2005). The second one is the significant R\&D investment at the national level coupled with lower innovation and commercialization capabilities at the industry level. This particular Chinese situation suggests that technology-based new ventures operating in transitional markets with plenty of emerging opportunities can improve their performance by adopting an EO strategy (Liu et al. 2014). However, these new firms may not have the capability and the time to develop the necessary resources internally (Peng 2001). Acquiring technology externally can help a firm to eliminate the high cost of internal R \& D (Noori 1990) as well as bring new products to market quickly (Capon, Glazer 1987; Lichtenthaler 2010). For this argument, Chinese TBNVs with a clear entrepreneurial orientation strategy may benefit further from external technology acquisition. Therefore, we hypothesize: 
H3: the interactive effect of ETA and EO positively moderates the relationship of EO and TBNV's performance in China.

The hypothetical relationship of the study is presented in Fig. 1.

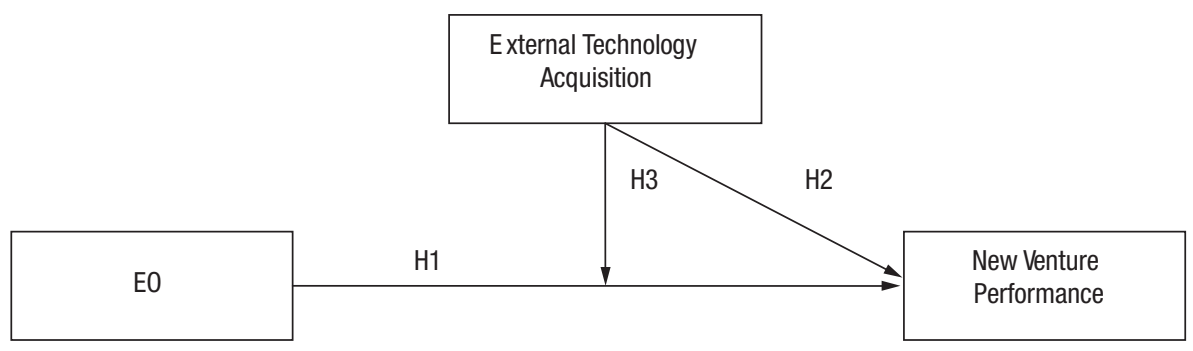

Fig. 1. Conceptual contingency model

\section{Data and methods}

\subsection{Research setting}

China's economic transition presents an ideal condition for quasi-experimental study (Meryer, Peng 2005). During China's economic transition from a central planning economy to a market-based economy, the business operational environment is more turbulent and dynamic than ever before (Tan 1996, 2005). With a rapidly growing market, the business competition intensifies while customer needs become more complex.

Several characteristics of China's dynamic economic environment have made the research setting valuable to test the above research hypotheses. These characteristics include: 1) a rapid industrial growth rate that afford firms to utilize an EO strategy to aggressively search for new opportunities; 2 ) the fast replacement rate of core products in various industries, which helps to raise firms' innovative intention; 3)the increased rate of technological change that helps to shape a firm's technological resource strategy; and finally, 4) the daily change rate of customers' needs, which impacts on a firm's resource acquisition and decision-making. Even though previous researchers have conducted studies on the impact of EO and technology resource, there have been few studies that focus on this particular research setting in a transitional economy. This study on EO and ETA in relationship with TBNV's performance in China's dynamic market is designed to fill in this literature gap.

\subsection{Sample}

To test the above hypotheses, data were collected from technology-based new firms in China, utilizing a questionnaire-survey approach. The samples were drawn from Northeast and Southeast China, including 500 firms from Changchun, Jilin and Tonghua cities in Jilin Province in the North and 300 firms from Fuzhou and Yongan cities in Fujian Province in the South. The reason for selecting the five cities in the two provinces is due to the fact that they are all middle-developed cities with a large number of recently 
created high-tech and small-medium-sized firms. While a central planning economy significantly influences the cities in the North, the cities in the South are mainly influenced by market force. This sample selection represents a good balance of China's South and North regions.

The local government of these target cities provided addresses and phone numbers of TBNVs in their region. For each of the five cities, a sample of small-medium sized industrial firms was sought, covering the main industrial regions with all types of private firms and across different industrial sectors. The majority of the firms in the sample are in manufacturing, communication, computer service, software, biology and medicine, which are the likely firms to form high-tech industry in China. This study concentrates on new ventures that are in operations for less than eight years (Zahra, Bogner 1999).

Data collection was implemented in two steps. Trained interviewers first telephoned the sample firms to request their cooperation in the study. Then, the founders of the sample firms were interviewed and asked to fill out the designed questionnaires on site. In total, 800 firms were approached and 123 firms completed the questionnaire, with an effective response rate of 15.38 percent. The reasons for non-participation included: 1) concerns over leakage of internal information; 2) occupied with important affairs at the time of the scheduled interview, hence not having the time to participate. Despite some of the drawbacks in the data collection process, the profile of the respondents and these high-tech firms in Table 1 shows a satisfactory representation of the population of interest. In terms of "The high technology industry typology standard of China" enacted by the National Bureau of Statistics of China, the sample enterprises fall in the hightech industry code $253,2665,27,368,376,40$, and 621 , including medical manufactory, communicational and electrical equipment manufactory and software service. The study sample truly reflects the characteristics of high-tech industry. The respondents are mostly "Board Chairman, CEO or Senior Managers" (72.4\%) who founded the business. Most of the firms (81\%) had less than 200 employees and 2010 is the cut-off year in terms of firm age. The sample is a good representation of small, technology-based new ventures in China. To eliminate any possible bias of non-respondent, $\chi^{2}$ a test was conducted between early respondents and late respondents, no statistically significant differences were found between the two groups across the key variables in the study, supporting the assumption that respondents were not different from non-respondents.

\subsection{Measures}

TBNV's performance: four items were used to measure TBNV's performance, including growth and financial performance as growth is often used as a proxy for business performance (Brush, VanderWerf 1992; Chandler, Hanks 1994). Meanwhile, firms also choose a trade-off between long-term growth and short-term profitability (Zahra 1991). To measure both aspects of TBNV's performance, we combined measures of financial performance (current net income and market share) and growth (growth rate of net income and growth rate of sales), and used a seven-point scale to measure the statement of items. This performance measure has been extensively used in past studies (Covin et al. 2006; Rauch et al. 2009). The Cronbach's $\alpha$ of the scale is 0.85 as shown in 
Table 2. Taking the sample size and model complexity into consideration the measurement model represents a good fit $\left(\chi^{2} / \mathrm{df}=1.08, \mathrm{GFI}=0.99, \mathrm{AGFI}=0.96, \mathrm{NFI}=0.99\right.$, $\mathrm{CFI}=0.99$, RMSEA $=0.03$ ).

Entrepreneurial orientation: it is widely acknowledged that there are four high quality measures of EO, e.g. (1) Covin and Slevin (1989) EO scale; (2) Miller's (1983) composite view of EO; (3) the Hughes and Morgan (2007) EO scale; and (4) a "type II" second-order formative EO scale by Diamantopoulos and Sigauw (2006). We chose to use the EO scale by Covin and Slevin (1989) because of its reflective nature and its easiness to administer in the Chinese environment.

For the purpose of the study, EO is employed as a high-order construct (Zahra, Covin 1995; Wiklund 1999; Green et al. 2008). Although innovativeness, risk-taking, and proactiveness are important characteristics of entrepreneurial firms, Cooper and Dunkelberg (1986) suggest that various paths to business ownership constitute different degrees of entrepreneurship and the entrepreneurial firms will present significant differences when compared with conservative firms. Thus, a high level of all three characteristics of entrepreneurial firms may be too narrowly defined for explaining some types of entrepreneurial behavior (Lumpkin, Dess 1996).

Table 1. Profile of responding organizations and respondents

\begin{tabular}{lc}
\hline \multicolumn{1}{c}{ Characteristics of respondents and new ventures } & Percent \\
\hline Respondents & \\
(1). Board Chairman & 31.3 \\
(2). CEO & 27.7 \\
(3). Senior Managers & 13.4 \\
(4). Department Directors & 20.5 \\
(5). Other Insiders & 7.1 \\
Number of Employee & \\
(1). 1-20 & 27.9 \\
(2). 21-50 & 20.7 \\
(3). 51-200 & 32.4 \\
(4). 201-500 & 9.0 \\
(5). 500-1000 & 1.8 \\
Firm Ages & \\
(1). <3 year & 14.9 \\
(2). 4-5 year & 22.4 \\
(3). 6-8 year & 63.7 \\
Industry & \\
(1). Telecommunication/Internet/computer service and software development & 19.5 \\
(2). Manufacture & 35.0 \\
(3). Biology and medicine & 8.9 \\
(4). Others & 36.6 \\
\hline
\end{tabular}


Table 2. Factor loadings and reliability

\begin{tabular}{|c|c|c|c|}
\hline Factors & Items & Loading & Cronbach's $\alpha$ \\
\hline $\begin{array}{l}\text { EO } \\
\chi^{2} / \mathrm{df}=1.191, \mathrm{p}=0.240 \\
\mathrm{GFI}=0.951, \\
\mathrm{AGFI}=0.904, \mathrm{NFI}= \\
0.953, \mathrm{CFI}=0.992 \\
\mathrm{RMSEA}=0.040\end{array}$ & $\begin{array}{l}\text { 1. First to introduces new line of } \\
\text { products/services, techniques and } \\
\text { technology } \\
\text { 2. Strong emphasis on R\&D, innovation } \\
\text { and technological leadership. } \\
\text { 3. Our innovations are so dramatic } \\
\text { that it is difficult to be imitated by our } \\
\text { competitors } \\
\text { 4. Strong preference for projects with } \\
\text { high risk and high return. } \\
\text { 5. Adopt bold and active actions to } \\
\text { achieve the business objective. } \\
\text { 6. Adopt a bold, aggressive posture in } \\
\text { order to explore potential opportunities. } \\
\text { 7. Adopt a very competitive and market } \\
\text { oriented posture. } \\
\text { 8. First to take initiative before our } \\
\text { competitors. } \\
\text { 9. Proactively develop many new lines } \\
\text { of products and services. }\end{array}$ & $\begin{array}{l}0.87 \\
0.88 \\
0.74 \\
0.78 \\
0.79 \\
0.78 \\
0.77 \\
0.83 \\
0.76\end{array}$ & 0.85 \\
\hline $\begin{array}{l}\text { ETA } \\
\chi^{2} / \mathrm{df}=1.122, \mathrm{p}=0.326 \\
\mathrm{GFI}=0.991, \\
\mathrm{AGFI}=0.954 \\
\mathrm{NFI}=0.992, \mathrm{CFI}=0.999 \\
\mathrm{RMSEA}=0.032\end{array}$ & $\begin{array}{l}\text { 10. Acquire majority of technology and } \\
\text { patents from outside. } \\
11 \text {. Dependent on other firms to supply } \\
\text { us with new technology. } 12 \text {. Using } \\
\text { business plan/vision to attract patents or } \\
\text { technology. } \\
\text { 13. Using firm reputation to attract } \\
\text { patents or technology. }\end{array}$ & $\begin{array}{l}0.72 \\
0.83 \\
0.93 \\
0.81\end{array}$ & 0.89 \\
\hline $\begin{array}{l}\text { Performance } \\
\chi^{2} / \mathrm{df}=1.081, \mathrm{p}=0.339 \\
\mathrm{GFI}=0.991, \\
\text { AGFI }=0.957 \\
\mathrm{NFI}=0.990, \mathrm{CFI}=0.999 \\
\text { RMSEA }=0.026\end{array}$ & $\begin{array}{l}\text { 14. Current net income } \\
\text { 15. Current market share } \\
\text { 16. Growth rate of net income } \\
\text { 17. Growth rate of sales }\end{array}$ & $\begin{array}{l}0.66 \\
0.80 \\
0.77 \\
0.83\end{array}$ & 0.85 \\
\hline
\end{tabular}

Hence, in this article, a second-order confirmatory factor analysis was conducted to test EO construct. After extensive personal interviews with CEOs of local high-tech firms in Changchun city, the nine-item scale by Covin and Slevin $(1989)^{1}$ was modified slightly to reflect a better understanding by the Chinese respondents, each of which focusing on innovativeness, risk-taking and proactiveness. One item in the original Covin/Slevin scale (undo-the-competitor posture) was modified as "Adopt a very competitive and market oriented posture" as the Chinese CEOs felt that "undo-the-competitor posture" was too negative. A seven-point Likert scale was used to measure the statements of

\footnotetext{
${ }^{1} 1$ An extensive discussion of EO scale can be found in an article by Covin and Wales (2012).
} 
items. In the second-order confirmatory factor, EO items first loaded on three independent constructs in a first-order model, and then these three dimensions load on one dimension in a second-order model. The Cronbach's $\alpha$ is 0.85 as shown in Table 2. This model exceeds an acceptable fit $\left(\chi^{2} / \mathrm{df}=1.19, \mathrm{GFI}=0.95\right.$, AGFI $=0.90, \mathrm{NFI}=0.95$, $\mathrm{CFI}=0.99$, RMSEA $=0.04$ ).

External technology acquisition: some researchers argue that TBNVs usually face resources constraint, thus it is very important for these TBNVs to attract external resource by their business plan, entrepreneurial vision and the reputation of the entrepreneurs or team (Brush et al. 2001; Roberts 1991b). External technology acquisition includes fully external activities such as fully functional technology from other firms through purchase and licensing (Capon, Glazer 1987; Narula 2001), and quasi-external activities such as technology alliance with other firms (Narula 2001; Schoenmakers, Duysters 2006). In this study, four items were developed based on the previous theoretical research to measure ETA of a TBNV. Two items were designed to measure fully external activities while the other two items were developed to measure quasi-external activities. A sevenpoint Likert scale was used to measure the statements of items. The Cronbach's $\alpha$ of the scale is 0.89 as shown in Table 2. The model represents an excellent fit $\left(\chi^{2} / \mathrm{df}=1.12\right.$, $\mathrm{GFI}=0.99, \mathrm{AGFI}=0.96, \mathrm{NFI}=0.99, \mathrm{CFI}=0.99, \mathrm{RMSEA}=0.03)$.

Control variables: firm size as measured by employees (Zahra, Neubaum 1998; Wiklund, Shepherd 2005; Stam, Elfring 2008), age (Zahra, Neubaum 1998; Wiklund, Shepherd 2005; Stam, Elfring 2008;), education level of the entrepreneur, and firm type (independent investment company or partnership) may influence the TBNV's performance. The respondents were asked the year of their firm foundation to measure firm age. The number of employees was used to measure the scale of the TBNV. The education level was measured by a range from " $0=$ middle school to $6=$ doctoral degree". A dummy variable was used to measure firm type, where $1=$ independent investment firm and $0=$ partnership.

\section{Research findings}

\subsection{Reliability and validity}

Reliability coefficients of 0.70 or higher are considered adequate for purposes of construct validation (Hair et al. 2010). Composite reliability is estimated by using Cronbach's $\alpha$ or composite reliability value. The measures used in this paper were adopted from the existing scale, previously validated and strongly grounded in the literature. These adapted measures were also tested in this study. Table 2 shows that the internal validities of the constructs remain strong in the Chinese context. The Cronbach's $\alpha$ of all factors are above 0.80 . These results suggest that the theoretical constructs show good psychometric properties within our Chinese study.

\subsection{Construct validity and discrimination validity}

Confirmatory factor analysis was conducted to test the construct validity and discrimination validity. A loading value of 0.70 is the suggested minimum level for item loadings 
on given scales (Hair et al. 2010). Table 2 shows that the loadings are all above the 0.70 level, except one performance item, implying a good model fit.

\subsection{Hierarchical linear regression}

Hierarchical regression modeling was utilized to test the theoretical hypotheses of EO, ETA and firm performance. The descriptive statistics and correlations of the variables are provided in Table 3. The correlation matrix implies that the control variables do not significantly correlate with independent variables. In further testing of the multicollinearity in higher-order models, multicollinearity diagnoses were applied. All of the variance inflation factors (VIF) are below the threshold value of 4.0 (Hair et al. 2010).

Table 3. Descriptive statistics and correlations matrix

\begin{tabular}{lcccccccc}
\hline & Mean & S.D. & 1 & 2 & 3 & 4 & 5 & 6 \\
\hline Firm age & 6.0 & 2.01 & 1 & & & & & \\
Firm size & 2.6 & 1.44 & $.41^{* *}$ & 1 & & & & \\
Education & 3.6 & 1.17 & .11 & -.11 & 1 & & & \\
Firm type & 0.2 & 0.43 & -.17 & -.01 & -.14 & 1 & & \\
EO & 5.3 & 0.86 & .09 & .15 & .14 & -.17 & 1 & \\
ETA & 4.2 & 1.47 & -.02 & .10 & .09 & -.05 & .11 & 1 \\
\hline Performance & 5.0 & 0.92 & .12 & $.42^{* *}$ & -.07 & -.04 & $.33^{* *}$ & $.33^{* *}$ \\
\hline
\end{tabular}

Note: ${ }^{* *}$ Correlation is significant at the 0.01 level (2-tailed).

Table 4. Results of regression model ${ }^{\mathrm{a}}$

\begin{tabular}{lccc}
\hline & \multicolumn{3}{c}{ Performance of TBNV $(\mathrm{N}=123)$} \\
\cline { 2 - 4 } \multicolumn{1}{c}{ Variables } & Model 1 & Model 2 & Model 3 \\
\hline Controls & & & \\
Firm age & -.04 & -.00 & .05 \\
Firm size & $.44 * * *$ & $.35^{* * *}$ & $.34^{* * *}$ \\
Education & -.02 & -.11 & -.08 \\
Firm type & -.04 & .01 & .02 \\
& & & \\
Independent & & $.29 * * *$ & $.22^{* *}$ \\
EO & & $.29 * * *$ & $.19^{*}$ \\
ETA & & & \\
& & & $.27 * *$ \\
Interaction & .18 & .36 & .42 \\
EO $\times$ ETA & .15 & .32 & .37 \\
$\mathrm{R}^{2}$ & .18 & .18 & .05 \\
Adjusted $\mathrm{R}^{2}$ & $5.35^{* * *}$ & $13.73^{* * *}$ & $8.42^{* *}$ \\
$\Delta \mathrm{R}^{2}$ & & & \\
F Change & & & \\
\hline
\end{tabular}

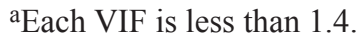

Notes: *, $\mathrm{p}<.05 ; * *, \mathrm{p}<.01 ; * * *, \mathrm{p}<.001$. 


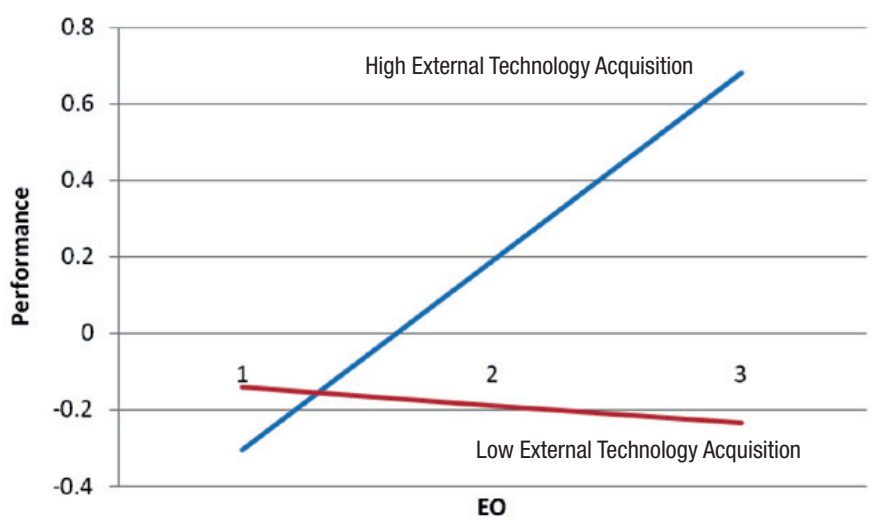

Fig. 2. Effect of interaction of EO and ETA on performance of TBNV

The research hypotheses were tested via three models: control variables, independent variables, and interactive variables as shown in Table 4. First, the effect of control variables on firm performance in Model 1 was tested, with $18.1 \%$ variance of firm performance explained by firm size. Second, in Model 2, the independent variables of EO and ETA were added over Model 1. An additional 18.4\% variance of firm performance was explained in Model $2(\mathrm{p} \leq .001)$. EO has a significant positive relationship with firm performance $(\beta=.292, \mathrm{p} \leq .001)$, which supports Hypothesis 1 . Meanwhile, ETA is also positively associated with firm performance $(\beta=.291, \mathrm{p} \leq .001)$, which supports Hypothesis 2. Finally, the interactive terms in Model 3 were tested, where the variation of TBNV's performance is explained further $\left(\triangle \mathrm{R}^{2}=5.2 \%, \mathrm{p} \leq .01\right)$. The interactive term between EO and ETA is significantly positive in relationship with TBNV's performance $(\beta=.270, \mathrm{p} \leq .01)$. This finding provides support for Hypothesis 3 .

Based on the regression coefficients in Table 4, the relationship was plotted between EO, ETA and TBNV's performance. Given the different value of ETA, two plots were allotted, dealing with interaction of EO and ETA on firm performance in Fig. 2.

\section{Discussions}

This study examines the relationship between EO and operational performance of technology-based new ventures in China in conjunction with the firms' decision to acquire technology externally. Drawn upon the previous studies, the current empirical investigation deepens our understanding of this complex relationship in a dynamic transitional environment through a contingency modeling. The study hypotheses are all supported.

Several contributions make this research significant. First, although the findings of most western studies suggest that EO as an independent variable significantly influences firm performance when the effects of other variables are controlled (Covin, Slevin 1989; Wiklund 1999; Real 2014), the studies of this relationship under Chinese conditions 
remain inconclusive (Luo et al. 2005; Tang et al. 2008; Tsai, Wang 2008). The current study findings not only validate the findings of the majority of previous studies, but also advance the argument to include TBNVs in this positive relationship. In another word, the current study finds that EO positively influences TBNV's performance. For technology-based new ventures, higher level of EO implies higher level of innovativeness, risk-taking and proactiveness that encourage TBNVs to pursue new opportunities and help achieve a higher performance level even in a dynamic environment in China's transitional economy.

Second, the current study confirms that the external technology acquisition positively moderates the relationship between EO and TBNV's performance. This contribution is especially significant in that no studies had investigated such relationship before, although relationship between EO and firm performance, and relationship between ETA and firm performance were confirmed independently by many previous studies. The current study provides an added value that a contingency approach of EO/ETA and firm performance is superior to simple EO/firm performance or ETA/firm performance model. In China's transitional economy, technology-based ventures usually hold a higher level of EO (Tan 2005). Meanwhile, these firms can at the same time implement an innovation strategy to acquire technology, patents and knowledge externally to help the firms to establish a competitive advantage more quickly. As argued in the previous studies (Covin, Slevin 1991) that entrepreneurial orientation is quite a resource-consuming strategy, external technology acquisition can certainly lessen the resource pressure on the firms as ETA facilitates and reduces the investment of R\&D and management risk. Thus, an external technology acquisition strategy can support the entrepreneurial strategy significantly in a technology-based firm.

The third contribution of the research is management related. Although our study has validated the relationship between EO and the performance of technology-based new ventures in China, TBNVs and new entrepreneurs can reach a higher performance level by utilizing both EO and external technology acquisition. TBNVs/entrepreneurs should keep in touch with external technology sources in order to improve the capability of technology acquisition. This approach will not only keep the resource-stressed TBNVs up front in innovation and technology development, but also lessen the resource pressure. A configuration of EO and ETA will certainly benefit TBNV's performance in China's dynamic environment.

\section{Limitations and future directions}

While the current study furthers research on the relationship between EO and firm performance in a contingency approach, there are some limitations. Firstly, the current study employs a cross-sectional data to test the hypotheses. This approach brings about doubt whether "EO affects performance over an extended period of time, or if it is a 'quick fix' where firm performance is temporarily affected" (Wiklund 1999). Thus a longitudinal research should be encouraged to test the hypothesized relationship between EO and performance of TBNVs. 
Further, there are also some limitations relating to conceptual constructs and measurements. The current study treats EO as a one-dimensional construct. Facing criticism from Lumpkin and Dess (1996) and Covin and Wales (2012), a relationship with multidimensions should be tested in future.

Finally, this study tests the relationship between EO and firm performance in a contingency model integrated with ETA in a dynamic transitional economy. Although the analysis framework is limited to the confines mentioned above, the results provide foundation for further understanding of the relationship between EO and firm performance in technology-based new firms. Furthermore, although the study findings may provide guidance to other emerging economies, the specific Chinese economic environment may limit the study's generalization. However, the current study does suggest that future research on TBNV's performance should involve the interaction between technological strategy and entrepreneurial strategy.

\section{Conclusions}

Although EO is beneficial to the improvement of a firm's performance, the relationship between EO and firm performance is often complicated by the country-specific environment, especially for technology-based firms in the transitional China (Zahra 1991; Smart, Conant, 1994; Tang et al. 2008; Liu et al. 2014). The following conclusions are drawn from the findings of the current research.

1. From the theoretical point of view, as previously identified in the literature review, EO and firm performance linkage tends to be inclusive due to the fact that this relationship is very much context specific. A conclusion is drawn here that the EO and firm performance relationship does exist in a transitional economy. Of course, this is to some extent to buttress the argument that this relationship is context specific and it is not appropriate to generalize this as a universal phenomenon. Further, this conclusion implies that this findings may be also true in other emerging economies that have similar characteristics as Chinese economy.

2. A second conclusion rests on the findings that EO facilitates TBNVs' performance specifically. Although extensive literature reviews indicate an inconclusive relationship between EO and firm performance, previous findings pretty much rest on empirical data drawn from mature industries. No study has actually dealt with technology based firms in this regard except a relevant study by Ahlstrom and Bruton (2002) which deals with the role of culture in shaping strategic actions by technology based firms. The current research is specifically targeting technology based new ventures in relationship of EO and performance. A positive relationship naturally gives rise to the contention that limited resources possessed by the new venture should not be an impediment to superior performance as long as proper strategies are pursued. This conclusion is especially significant to technology based new venture in emerging economies where resources are often not readily available.

3. A significant conclusion is the empirical support that this study generates in regard to the technology acquisition. Like most developing countries, especially emerging 
economies, firms are often faced with the choice of buying or developing technology due to the resource constraints and lower level of research and development capability. Sometimes acquiring external technology may be a better choice for new ventures, especially in developing countries. The empirical findings from the current study actually lends support to the strategic choice that external technology acquisition not only improves the performance of TBNVs, but actually also strengthens the relationship between EO and new ventures' performance. This conclusion is especially important in that the current research provides a solution to the dilemma that ETA may render a firm dependent on outside sources and EO may encounter internal resource constraints. A contingency solution may ultimately be the best way to maximize a firm's performance, especially for TBNVs. Of course, in correspondence with conclusion one, this conclusion may be context specific and applies only to those new ventures in emerging economies.

Overall, the findings of current study enrich the application of entrepreneurial and innovation strategy in managerial practice and offer a new direction for further studies by scholars with an interest in organizational strategy, especially in entrepreneurial strategy orientation and innovation strategy.

\section{Acknowledgement}

The authors are grateful to the editor of JBEM and four anonymous reviewers for their insightful comments which greatly helped improve the paper. The authors also acknowledge Prof. Dirk De Clercq's comments on an earlier draft. This research is financial supported by the National Natural Science Foundation of China (Key Project Grant No. 71232011 and General Project Grant No. 71172019).

\section{References}

Ahlstrom, D.; Bruton, G. D. 2002. An institutional perspective on the role of culture in shaping strategic actions by technology-focused entrepreneurial firms in China, Entrepreneurship Theory and Practice 26(4): 53-69.

Alegre, J.; Chiva, R. 2013. Linking entrepreneurial orientation and firm performance: the role of organizational learning capability and innovation performance, Journal of Small Business Management 51(4): 491-507.

Avlonitis, G.; Salavou, H. 2007. Entrepreneurial orientation of SME, product innovativeness, and performance, Journal of Business Research 60: 566-575.

http://dx.doi.org/10.1016/j.jbusres.2007.01.001

Bamiatzi, V.; Kirchmaier, T. 2014. Strategies for superior performance under adverse conditions: A focus on small and medium-sized high-growth firms, International Small Business Journal 32(3): 259-284

Boso, N.; Story, V.; Cadogan, J. 2013. Entrepreneurial orientation, market orientation, network ties, and performance: Study of entrepreneurial firms in a developing economy, Journal of Business Venturing 28(6): 708-727.

Brush, C.; Vanderwerf, P. 1992. A comparison of methods and sources for obtaining estimates of new venture performance, Journal of Business Venturing 7(2): 157-170.

http://dx.doi.org/10.1016/0883-9026(92)90010-O 
Brush, C.; Greene, P.; Hart, M. 2001. From initial idea to unique advantage: the entrepreneurial challenge of constructing a resource base, The Academy of Management Executive 15(1): 64-78. http://dx.doi.org/10.5465/AME.2001.4251394

Bruton, G.; Ahlstrom, D. 2003. An institutional view of China's venture capital industry: explaining the difference between China and the West, Journal of Business Venturing 18: 233-259. http://dx.doi.org/10.1016/S0883-9026(02)00079-4

Bruton, G.; Lan, H.; Lu, Y. 2000. China's township and village enterprises: Kelon's competitive advantage, Academy of Management Executive 14: 19-29.

Buckley, P.; Park, B. 2014. Realized absorptive capacity, technology acquisition and performance in international collaborative formations: an empirical examination in the Korean context, Asia Pacific Business Review 20(1): 109-135.

Cai, L.; Liu, Q.; Zhu, X.; Deng, S. 2014. Market orientation and technological innovation: the moderating role of entrepreneurial support policies, International Entrepreneurship and Management Journal (DOI) 10.1007/s11365-013-0290-3

Capon, N.; Glazer, R. 1987. Marketing and technology: a strategic coalignment, Journal of Marketing 51(3): 1-14. http://dx.doi.org/10.2307/1251644

Chandler, G.; Hanks, S. 1994. Founder competence, the environment, and venture performance, Entrepreneurship Theory and Practice 18(3): 77-89.

Chow, I. 2006. The relationship between entrepreneurial orientation and firm performance in China, S.A.M. Advanced Management Journal 71(3): 11-20.

Cohen, W.; Levinthal, D. 1990. Absorptive-capacity - a new perspective on learning and innovation, Administrative Science Quarterly 35(1): 128-15. http://dx.doi.org/10.2307/2393553

Cools, E.; Van den Broeck, H. 2008. The hunt for Heffalump continues: can trait and cognitive characteristics predict entrepreneurial orientation, Journal of Small Business Strategy 18(2): $23-41$.

Cooper, A.; Dunkelberg, W. 1986. Entrepreneurship and paths to business ownership, Strategic Management Journal 7: 53-68. http://dx.doi.org/10.1002/smj.4250070106

Covin, J.; Slevin, D.1989. Strategic management of small firms in hostile and benign environments, Strategic Management Journal 10: 75-87. http://dx.doi.org/10.1002/smj.4250100107

Covin, J.; Slevin, D.1991. A conceptual model of entrepreneurship as firm behavior, Entrepreneurship Theory and Practice 16(1): 7-25.

Covin, J.; Wales, W. 2012. Measurement of entrepreneurial orientation, Entrepreneurship: Theory and Practice July: 677-702. http://dx.doi.org/10.1111/j.1540-6520.2010.00432.x

Covin, J.; Green, K.; Slevin, D.2006. Strategic process effects on the entrepreneurial orientationsales growth relationship, Entrepreneurship Theory and Practice 30: 57-81.

http://dx.doi.org/10.1111/j.1540-6520.2006.00110.x

Diamantopoulos, A.; Siguaw, J. 2006. Formative versus reflective indicators in organizational measure development: a comparison and empirical illustration, British Journal of Management 17: 263-282. http://dx.doi.org/10.1111/j.1467-8551.2006.00500.x

Fries1, M. 2012. Knowledge Acquisition Strategies and Company Performance in Young High Technology Companies, British Journal of Management 32(9-10): 560-567.

Green, K.; Covon, J.; Slevin, D. 2008. Exploring the relationship between strategic reactiveness and entrepreneurial orientation scale, Journal of Business Venturing 26(1): 61-78.

Global Entrepreneurship Monitor (GEM). 2010. Global Report.

Hair, J.; Anderson, R.; Tathum, R.; Black, W.2010. Multivariate data analysis with readings. New York: Macmillan. 
Hughes, M.; Morgan, R. E. 2007. Deconstructing the relationship between entrepreneurial orientation and business performance at the embryonic state of firm growth, Industry Marketing Management 36: 651-661. http://dx.doi.org/10.1016/j.indmarman.2006.04.003

Jones, G.; Lanctot, A.; Teegen, H. 2000. Determinants and performance impact of external technology acquisition, Journal of Business Venturing 16: 255-283. tp://dx.doi.org/10.1016/S08839026(99)00048-8

Lau, C.; Busenitz, L.2001. Growth intentions of entrepreneurs in a transitional economy: The People's Republic of China, Entrepreneurship Theory and Practice 26(1): 5-20.

Lau, C.; Yiu, D.; Yeung, P.; Lu, Y. 2008. Strategy orientation of high-technology firms in a transitional economy, Journal of Business Research 61: 765-777.

http://dx.doi.org/10.1016/j.jbusres.2007.07.031

Liu, H.; Ding, X.; Guo, H.; Luo, J. 2014. How does slack affect product innovation in high-tech Chinese firms: The contingent value of entrepreneurial orientation Asia Pacific Journal of Management 31(1): 47-68.

Lichtenthaler, U. 2010. Organizing for external technology exploitation in diversified firms, Journal of Business Research 63: 1245-1253. http://dx.doi.org/10.1016/j.jbusres.2009.11.005

Luo, X.; Zhou, L.; Liu, S. 2005. Entrepreneurial firms in the context of China's transition economy: an integrative framework and empirical examination, Journal of Business Research 58: 277-284. http://dx.doi.org/10.1016/S0148-2963(03)00159-0

Lumpkin, G.; Dess, G.1996. Clarifying the entrepreneurial orientation construct and linking it to performance, Academy of Management Review 21(1): 135-172.

Meryer, K.; Peng, M. 2005. Probing theoretically into Central and Eastern Europe: transactions, resources, and institutions, Journal of International Business Studies 36(6): 600-621.

http://dx.doi.org/10.1057/palgrave.jibs.8400167

Miller, D. 1983. The correlates of entrepreneurship in three types of firms, Management Science 29: 770-791. http://dx.doi.org/10.1287/mnsc.29.7.770

Miller, D. 1987. Strategy making and structure: analysis and implications for performance, Academy of Management Journal 30(1): 7-32. http://dx.doi.org/10.2307/255893

Narula, R. 2001. Choosing between internal and non-internal R\&D activities: some technological and economic factors, Technology Analysis and Strategic Management 13(3): 365-387.

http://dx.doi.org/10.1080/09537320120088183

Noori, H. 1990. Managing the dynamics of new technology. New Jersey: Prentice Hall.

Ortega, M. 2010. Competitive strategies and firm performance: technology capabilities' moderating roles, Journal of Business Research 63: 1273-1281.

http://dx.doi.org/10.1016/j.jbusres.2009.09.007

Pearce, J.; Fritz, D.; Davis, P. 2010. Entrepreneurial oreintation and tehperformance of religious congregations as predicted by rational choice theory, Entrepreneurship Theory and practice 34(1): 219-231. http://dx.doi.org/10.1111/j.1540-6520.2009.00315.x

Peng, M. 2001. Business strategies in transition economies, Academy of Management Review 26(2): 311-313. http://dx.doi.org/10.5465/AMR.2001.4378031

Peng, M. 2003. Institutional transitions and strategic choices, Academy of Management Review 28(2): 275-296.

People's Daily. 2011. China's 12th five Year plan, March 21, page 6.

Rauch, A.; Wiklund, J.; Lumpkin, G.; Frese, M. 2009. Entrepreneurial orientation and business performance: an assessment of past research and suggestions for the future, Entrepreneurship: Theory and Practice 33: 761-787. http://dx.doi.org/10.1111/j.1540-6520.2009.00308.x 
Real, J.; Roldan, J.; Leal, A. 2014. From entrepreneurial orientation and learning orientation to business performance: analyzing the mediating role of organizational learning and the moderating effects of organizational size, British Journal of Management 25(2):186-208.

Roberts, E.1991a. Entrepreneurs in high technology. New York: Oxford University Press. http://dx.doi.org/10.1093/acprof:oso/9780195067040.001.0001

Roberts, E. 1991b. The technological base of the new enterprise, Research Policy 20: 283-298. http://dx.doi.org/10.1016/0048-7333(91)90090-D

Schoenmakers, W.; Duysters, G. 2006. Learning in strategic technology alliance, Technology Analysis and Strategic Management 18(2): 245-264. http://dx.doi.org/10.1080/09537320600624162

Shan, W. 1990. An empirical analysis of organizational strategies by entrepreneurial high technology firms, Strategic Management Journal 11(2): 129-139.

http://dx.doi.org/10.1002/smj.4250110205

Smart, D.; Conant, J.1994. Entrepreneurial orientation, distinctive marketing competencies and organizational performance, Journal of Applied Business Research 10: 28-38.

Soininen, J.; Martikainen, M.; Puumalainen, K.; Kylaheiko, K. 2012. Entrepreneurial orientation: growth and profitability of Finnish small and medium-sized enterprises, International Journal of Production Economics 140: 614-621. http://dx.doi.org/10.1016/j.ijpe.2011.05.029

Stam, W.; Elfring, T. 2008. Entrepreneurial orientation and new venture performance: the moderating role of intra- and extra-industry social capital, Academy of Management Journal 51(1): 97-111. http://dx.doi.org/10.5465/AMJ.2008.30744031

Tan, J. 1996. Regulatory environment and strategic orientations in a transitional economy, Entrepreneurship Theory and Practice 21(1): 31-46.

Tan, J. 2005. Venturing in turbulent water: a historical perspective of economic reform and entrepreneurial transformation, Journal of Business Venturing 20(5): 689-704.

http://dx.doi.org/10.1016/j.jbusvent.2004.09.002

Tan, J. 2007. Phase transitions and emergence of entrepreneurship: the transformation of Chinese SOEs over time, Journal of Business Venturing 22: 77-96.

http://dx.doi.org/10.1016/j.jbusvent.2005.09.002

Tang, J.; Tang, Z.; Marino, L. 2008. Exploring an inverted U-shape relationship between entrepreneurial orientation and performance in Chinese ventures, Entrepreneurship Theory and Practice 32(1): 219-239. http://dx.doi.org/10.1111/j.1540-6520.2007.00223.x

Teece, D. 1986. Profiting from technological innovation: implications for integration, collaboration, licensing and public policy, Research Policy 15(6): 285-305.

http://dx.doi.org/10.1016/0048-7333(86)90027-2

Tsai, K.; Wang, J. 2008. External technology acquisition and firm performance: a longitudinal study, Journal of Business Venturing 23(1): 91-112.

http://dx.doi.org/10.1016/j.jbusvent.2005.07.002

Voss, Z.; Voss, G.; Moorman, C. 2005. An empirical examination of the complex relationships between entrepreneurial orientation and stakeholder support. European Journal of Marketing 39(9/10): 1132-1150. http://dx.doi.org/10.1108/03090560510610761

Wales, W.; Parida, V.; Patel, P. 2013a. Too much of a good thing? Absorptive capacity, firm performance, and the moderating role of entrepreneurial orientation, Strategic Management Journal 34(5): 622-633.

Wales, W.; Gupta, V.; Mousa, F. 2013b. Empirical research on entrepreneurial orientation: an assessment and suggestions for future research, International Small Business Journal 31(4): $357-383$. 
Watkins-Mathys, L.; Foster, M. 2006. Entrepreneurship: the missing ingredient in China's STIPs? Entrepreneurship and Regional Development 18(3): 249-274.

http://dx.doi.org/10.1080/08985620600593161

Wiklund, J. 1999. The sustainability of the entrepreneurial orientation-performance relationship, Entrepreneurship Theory and Practice 24(1): 39-50.

Wiklund, J.; Shepherd, D. 2005. Entrepreneurial orientation and small business performance: a configurationally approach, Journal of Business Venturing 20: 71-91.

http://dx.doi.org/10.1016/j.jbusvent.2004.01.001

Zahra, S. 1991. Predictors and financial outcomes of corporate entrepreneurship: an exploratory study, Journal of Business Venturing 6(4): 259-285.

http://dx.doi.org/10.1016/0883-9026(91)90019-A

Zahra, S. 1996. Technology strategy and performance: a study of corporate-sponsored and independent biotechnology ventures, Journal of Business Venturing 11(4): 289-321.

http://dx.doi.org/10.1016/0883-9026(95)00128-X

Zahra, S.; Bogner, W.1999. Technology strategy and software new ventures' performance: exploring the moderating effect of the competitive environment, Journal of Business Venturing 15(2): 135-173. http://dx.doi.org/10.1016/S0883-9026(98)00009-3

Zahra, S.; Covin, J. 1995. Contextual influence on the corporate entrepreneurship-performance relationship: a longitudinal analysis, Journal of Business Venturing 10: 43-58.

http://dx.doi.org/10.1016/0883-9026(94)00004-E

Zahra, S.; Neubaum, D. 1998. Environment adversity and the entrepreneurial activities of new venture, Journal of Development Entrepreneurship 3(2): 123-140.

Zhou, K.; Li, C. 2012. How knowledge affects radical innovation: knowledge base, market knowledge acquisition, and internal knowledge sharing, Strategic Management Journal 33(9): 109001102.

Li CAI ( $\mathrm{PhD}$, Jilin University, China) is Vice President and Professor of management at Jilin University, China. Concurrently she is also director of the Centre of Enterprise Research at Jilin University. She has published widely in the field of entrepreneurship and is a recognized expert on enterprise reform in China.

Qing LIU (PhD, Jilin University, China) is a Research Fellow at the Center of Enterprise Research, Jilin University and has published a number of articles in the field of entrepreneurship and technological innovation.

Shengliang DENG ( $\mathrm{PhD}$, Boston University, USA) is Professor of international business and marketing at Goodman Business School, Brock University, Canada. He is the author of nine management books and has published numerous research articles in North America and Europe. His main research interests include international business/marketing strategies and enterprise reform in emerging markets.

Dan CAO (PhD, University of Hull, UK) is an Assistant Professor of marketing in the School of International Business Administration, Zhejiang International Studies University. She has published a number of papers in the field of marketing. 